\title{
Input-Output Interplay in Indonesian EFL Classrooms: A Conversational Analytical Study
}

\author{
Yetti Zainil \\ Deakin University \\ Melbourne, Australia \\ Doi:10.5901/ajis.2013.v2n3p497
}

\begin{abstract}
Although classroom interaction has received a great deal of focus during the last 40 years, its investigation from a conversation analytic stance using video recordings and stimulated recall interviews is rather limited, especially at the primary schools level. This paper presents the findings of a study on actual classroom practices in primary schools in West Sumatra, Indonesia, specifically, the language used by teachers and its impact on the language used by students in EFL classrooms. Taking as a basic premise that exposure to the foreign language is conducive to language learning, transcript of classroom discourse were analysed. This will contribute to research on classroom interaction by elucidating various aspects of turn-taking and sequence organization of talk at school, and by specifying the exact constraints under which participants -teachers and students operate. The classroom data presented reveal teachers' variation and frequency range in oral input and students' output. There was a modest use of $L 1$ and a greater impact of the language used by teacher on students language output. The results suggest that students' language output was influenced by teachers' language choice. While not indicative of a cause-effect relationship, teachers might wish to consider encouraging quality of her target language use as well as quantity.
\end{abstract}

Key words: Conversation analysis, teachers' input, students' output, language foreign language classroom.

\section{Introduction}

English was introduced as an elective subject into elementary schools in Indonesia in 1990. However, at that time, there was no legislation regarding policy on teaching qualifications for English language teachers, and no guidelines on English language teaching and learning at the elementary school level. The 1994 English curriculum document aimed to support a pathway towards global competitiveness (Depdikbud 1993) and highlighted the importance of communicative competence as the main goal of English foreign-language learning in Indonesian elementary schools.

In 2004, the Ministry of Education of Rpublic of Indonesia published a new curriculum, the 2004 Curriculum which is well known as the Competence Based Curricullum [Kurikulum Berbasis Kompetensi-KBK]. This curriculum, shortly after, in 2006, was modified in such a way as to highlight the importance of using English (TL) as the main language input in the language classroom (Diknas 2006).

However, little is known about the practice of teaching English in elementary schools in Padang, and available information is based largely from anecdotal evidence. One question of importance in the context of achieving the aim of communicative competence among students is the language that is used most in classroom interaction. In Padang, most classes are teacher-fronted (see Musumeci 1996), where the teacher leads the class and provides the main source of language input for students. Students receive an average of 70 minutes of English instruction per week. The teachers are non-native speakers of the TL (English), and there is virtually no communicative need to use English outside the classroom. In fact, students do not hear much spoken English either inside or outside the classroom (Diknas 2010). For the aforementioned reasons, exposure to English in use in Padang is limited, in both social and educational settings. Accordingly, the issue of the language employed in teaching EFL classes in West Sumatra, and more generally across Indonesia, deserves serious attention. This paper examines the relationship between teacher input in the target language and its influence on students' output in terms of language choice (SL or TL) in EFL classrooms at the primary schools level in Padang, West Sumatra, Indonesia. 


\section{Literature review}

\section{Input-Output interplay in EFL classrooms}

The similarity in the processes involved in first language/second language (hereafter referred to as L1/SL respectively) and target language (TL) acquisition is not known. However, many TL learners rely, in the same way as first language (L1/SL) learners, on oral input as the primary source of the target language (Krashen 1982, Morata \& Coule 2012, Wong 2011). In terms of language input, teacher talk functions as the input in the EFL classroom which is important for the process of language acquisition (Nunan 1991) and the active use of the target language by the students is considered to be an integral part of language acquisition process (Nunan 1999). However, there has been an interesting debate in SLA concerning the role of input.

Despite the debate, current SLA research appears to consider the language the teacher uses as a source of language input in instructional contexts ( Ellis 1994, Lightbown 1985, Long 1996, Littlewood \& Yu 2011). According to Krashen (1982), it is possible for the language learner to acquire the language without practicing talking, what is important is input. 'Input' refers to language addressed to learner through any means of delivery (Krashen 1985).

However, Ellis (1994), Long (1983), Swain (1985) argue that although language input is essential for acquisition, input alone is insufficient; another necessity for successful acquisition to occur is interaction. Interactions are important because learners can improve their language through interaction as they listen to their teachers, and then they can use all that they have learned for communication. This kind of activity is seen as promoting their language development which will lead to comprehensible output (Swain \& Lapkin 1995).

Maximising comprehensible language input as well as interaction is the ultimate goal in a language-learning situation, as this is an important aid to acquisition. Consequently, teachers should consider the language they use in the classroom, because the language they use function as the input and can serve to elicit output. On this basis, it is important to discuss teacher talk in FL classroom.

\section{Teacher talk in language classroom}

Despite the rich and contextual research on the role of teacher talk, much of the research on teacher talk has mainly focused on its amount (quantity) and mainly done in the classroom where language policy emphasizes the target language use. The notion of "teacher talk too much" has perhaps acted as barrier to evaluating teacher talk as language input. However, what may be important is not only so much the quantity of teacher talk, but also how teachers talk, what language they use, and whether they talk in the right kind of way to aid students' language development?

There are debates and arguments centred whether teachers should use TL strictly (e.g. Chambers 1992, Cummin 2007, Krashen 1985), or allow limited use of L1/SL as the medium of instruction in the EFL classroom (Anton \& DiCamilla 1998, Brook \& Donato, Cook 2001, Duff \& Polio 1990, Storch \& Wiggleworth 2003). Turnbull \& Arnett (2002) report their review of studies in several countries that teachers should aim to maximum use of the TL. A language classroom should be provided with an environment in which students can contribute to learning activities and maximise their use of the language (van Lier 2004).

There is no question that the use of the TL represents current mainstream thinking in the field of SL/EFL teaching where learners have little opportunity to hear and use the TL inside and outside the classroom (Ellis 1985, Dailey-O'Cain 2009). However, there also exists a body of literature in favour of some use of $L 1$ of the students with different views on the extent to which and the situation in which the L1 should be used (e.g. Atkinson 1985, Cook 2001, Storch \& Wigglesworth 2003). Raschka et al. (2009) discuss that aviodance of using the L1 is unlikely to occur, especially when the teacher ansd learners share the same first language. Their views imply that in practical terms teachers cannot avoid using the L1.

Although the literature states L1 use to some extent, various researchers have also warned of the detrimental effects of its over-use in EFL, and do not support its random use (Atkinson 1987, Raschka et al. 2009). Cook (2001) highlights that teachers need to ensure that there is a critical reflection around the moderate and judicious use of L1/SL in the language classroom. To put into practice these scholars ideas of the maximum and optimal use of L1 in a classroom is difficult (Zacharias 2011) since teachers sometimes do not realize themselves when they have used L1 (Polio \& Duff 1994).

Despite what language is used in the language classroom, it is important to judge or assess teacher-talk by reference to its quantity and its quality (Cullen 1998). Supporting Cullen (1998) and Thornbury (1996), Lei (2009: 75) 
notes that "good teacher talk as an input is evaluated in terms of its quality, not only quantity". This is due to state that there is a tendency for teachers to control the patterns of communication. In other word, the teacher decide who, when, how to talk in the classroom (Johnson 1995, Clifton 2006) and also the language they use in the classroom.

Some researches have investigated the syntactic aspects of teacher talk ( e.g. Gaies 1977, Wesche \& Ready 1985). Gaies concludes that the speech of those teachers in his research when speaking with their students was slower than that when speaking with their peers. Wesche \& Ready (1985) investigated the speech of an English professor and a French professor in two university psychology class. These two professor conducted the lesson in the student's second language, English or French. Both English professor and French professor significantly used more words and rephrased self-repetition with their L2 classroom than with their L1 classes. Ellis (1985) in his study counted the same teacher selfrepetitions on two occasions in classroom interactions with two ESL secondary beginners students, and found a significant decrease in frequency over an observation period of six months. His findings are in accordance with Gaies (1977) and Wesche \& Ready (1985) findings, where it seems that the teacher is able to make an implicit judgment about their students' levels in terms of their use of the language in the classroom.

Regarding the focus of this paper, it should be pointed out that the focus of the present paper is essentially on the techers' TL as an input, as well as on the use of the L1 within the foreign language context; teacher talk is the main language input available in the classroom and, its impacts on students' language output is critical. Neil (1977), Turnbull \& Arnetts (2002) and Singleton \& Ryan (2002) discusses a rationale for the use of TL in the language classroom. They conclude that the use of TL by the teacher improved the student's achievements. Their findings reveal that the role of the $T L$, as the language input leading to student TL language output, is critical. Hence, the students should be given opportunity to listen and then use the TL.

\section{Methodology}

The following section presents participants, data and data analysis of this study.

\section{Participants}

The participants of this study, both teachers and students, came from two elementary schools in Kota Padang, West Sumatra, Indonesia - Sekolah Dasar Percobaan Negeri Kota Padang and Sekolah Dasar Pembangunan UNP Padang. These schools have included English-language instruction in the curriculum for at least the last 10 years. The former is a pilot school for elementary schools in Kota Padang (Diknas No: 302/C2/DL/2009); the pilot school acts as a testing ground for subject, curriculum and methodology development, and as a model for elementary schools in the surrounding Kota Padang area. It is located in the centre of Padang City. The latter is linked to the Padang State University and the program offered there is developed in accordance with the university; thus, English faculty members from the university are represented in the English-language program at the school.

There were three teachers participating in this research from the two elementary schools mentioned above: one teacher from grade 5 and one teacher from grade 6 of Sekolah Dasar Percobaan Padang, and one teacher who taught grade 5 and 6 of Sekolah Dasar Pembangunan Padang.

The number of students in each class participating in this research ranged from 20 to 25 . One of the aims of this research was to investigate student language output; Grade 5 and 6 students had been selected on the assumption that students from these two grades, having received significantly more instruction in English language, produced more output than students from lower grades.

The classes selected for classroom recordings were the ones in which teacher $A, B$, and C taught English. Three classes chosen for this study were bilingual classes in which the students spoke Minangkabau language as their L1 and Bahasa Indonesia as their SL and were learning English as TL. All classes were mixed -ability classes with different levels of English competence.

All the participating students were between 10 to 12 years of age. The majority did not have an English-speaking background, except that they had learned English from first grade in elementary school. They learned English once a week, each period being 70 minutes long. Effectively, the two schools run for 34 weeks a year; thus, they have potentially had 132 sessions of English-language instruction. 


\section{Data}

The data were collected in a 7-week period over the second semester in 2013 from early January till end of February 2013. The researcher visited each school on a weekly basis. Each classroom session was 70 minutes per week. Some classroom visits, however, were cancelled due to public holidays and schools events such as pre-final exam and religious events. The total number of visits varied between three teachers. It was difficult to reschedule a visit for the same week because English subject was taught once a week. As a result, the researcher conducted a total of 20 classroom observations. These observations were video recorded.

\section{a. Video-recording of classroom sessions}

Data concerning teacher-student interaction during the class was collected by means of video-recording. The recordings were taken place in the natural setting of the classroom, where the researcher was visible to both students and the teacher, and they all knew the reason for the researcher's presence in the classroom. One camera focused on the teacher, but was set at a wide enough angle to video-record the entire class. Another camera was placed on the teacher's table in front of the class, facing the students for the purpose of recording student participants. Although all the three teachers had two classes to teach, only one of their classes was chosen to be video-recorded. This class was chosen randomly. Accordingly, in total there were 21 hours of video recordings.

The recordings focused on the teacher's and student's language selection and thus were limited to interactions between the teacher and the student(s). An important consideration in the design of this study was to measure teachers and students as they were addressing and interacting each other as a class rather than when the students were working together in pairs or small groups. The data, therefore, did not include recordings of interaction among students, in pair or group activities.

\section{b. Detailed note-taking}

It was anticipated that technical problems might arise with the video camera on some occasions and some phenomena might not be well captured by it. For this purpose, the researcher took detailed notes or photos during the class, describing classroom events, commenting on their functions as they were observed. Anything that was written on board was also written down (photo), alongside who wrote it. These extra pieces of information turned out to be very useful during the transcribing and analysing of the video recordings, helping the researcher to recall the incidents more easily and also to be able to put some of the incidents into the wider contexts.

\section{c. Stimulated recall interviews}

In the present study, the stimulated recall interview was used for two reasons: to prompt the teacher to reflect on her teaching practice; and to investigate the teacher's specific reasons for using particular instances (utterances) of Bahasa Indonesia (SL) or English (TL) at particular points in the course of their teaching. The stimulated recall interviews were semi-structured, with a set of questions guiding the interviews. The researcher asked teachers how often they believe they used English during the class, why they changed to SL or TL in certain instances, and what their general teaching philosophy was in relation to the language of choice in the classroom. The participants were given the option to be interviewed in English or Bahasa Indonesia. They chose Bahasa Indonesia. Both the researcher and the teacher were freed at any time to stop the recording to provide comment.

The interviews took place after the completion of the entire set of classroom recordings in order that the interview questions do not influence the teachers' classroom practice. The researcher selected two lessons for each teacher which contained the greatest amount of teacher-student verbal interaction. Thus, each of the selected lessons represented a rich sample of teacher talk. Nunan (1992) notes that this technique has at least two advantages: to produce insights into the teaching and learning process, which would be hard to obtain by other means; and to make the class participants' voice heard.

\section{d. Data analysis}

The present study investigated the classroom discourse in terms of what the language used by the teacher and its impact 
on the students' language output in terms of language used. The quantitative analysis was used to document the teachers' language choices. The qualitative analysis was used to analyse the recordings of classroom interaction, the stimulated interview and the field notes taken during the recordings of classroom interaction to see which teacher among the three teacher participants who could elicit more students' output. It was also used to see what impact teachers' language choice has on the students' language output in terms of the language used.

Therefore, a more open exploration of the data was required, which suggested favouring a Conversation Analysis (CA) approach. CA can help pictures what actually happens in the classroom which largerly determines the degree to which learning and learning outcomes are realised (Kumaradivelu 1999). The data were transcribed and contextually relevant information was also provided in the transcript.

A word count method was used to determine the amount of spoken language in the classroom, and the distribution of the two different language Bahasa Indonesia (SL) and English (TL) in the speech of the teachers and the students. This analysis was carried out in order to be able to find out what language teachers used most in the EFL classroom, English (SL) or Bahasa Indonesia (TL). Further analysis using qualitative analysis was applied to find out what really happened in Teacher A, Teacher B and Teacher $\mathrm{C}$ class. This analysis made it possible to make systematic comparisons amongs the different teachers to find out what impact does the teacher's language use have on students' language output.

\section{Results/ discussion}

The percentage for the teacher's choice of language types are presented in the following tables. These tables present the amount of teacher talk in 4 sessions and their respective classes as counted as prencentage of the total number of words spoken by the three teachers and their respective class in particular language. In this research teacher talk consists of two languages in the classroom, Bahasa Indonesia (SL) and English (TL).

\section{Language use in the classroom discourse}

Tabel 1. The percentage of SL+TL used in 4 lessons

\begin{tabular}{|l|l|l|}
\hline \multirow{3}{*}{ Bahasa Indonesia (SL) + English (TL) } & Teacher & Students \\
\cline { 2 - 3 } & $(\%)$ & $(\%)$ \\
\cline { 2 - 3 } & $80.5 \%$ & $19.5 \%$ \\
\hline
\end{tabular}

Table 1 displays the quantity of words the teachers and the students used, Bahasa Indonesia (SL) and English (TL). Of the total number of words spoken in the class during teacher and students interactions in whole class activities accounted for $80.5 \%$ of the SL and TL spoken by the teachers. It means that the students accounted for only $19.5 \%$ of Bahasa Indonesia and English spoken in the classroom. It can be concluded that teachers in this research used more words than their students in Bahasa Indonesia and English. Although it is important not to interpret these results as the word estimate are approximate, the results do indicated that the teachers dominate the classroom discourse in 4 lessons. This finding is similar to previous studies in teacher talk (Polio \& Duff 1994, Macaro 2001, Rolin-lanziti \& Bronlie 2002, Morata 2011) that student talk accounts for an average of less than $30 \%$ of talk in classroom discourse.

It should be also noted that the classes appeared to be very much teacher-centred and the data obtained support this notion. Not only did teachers direct all of the activities, but they spent much more time speaking than the students. This finding appears contradict one of the current trends in language teaching where teachers are encourage to develop a more student-centered classroom (see van Lier 2001, Paul 2003). Further analysis was done to look at what language were teachers used most, SL or TL.

Table 2 presents the percentage of teacher talk in 4 sessions of each teacher as counted as percentages of the total number of words spoken by three teachers in SL and TL. 
Table 2. The percentage of SL and TL used in 4 sessions.

Teacher talk

\begin{tabular}{|l|l|}
\hline $\mathrm{SL}$ & $\mathrm{TL}$ \\
\hline$(\%)$ & $(\%)$ \\
\hline $33.7 \%$ & $66.4 \%$ \\
\hline
\end{tabular}

Table 2 shows that the three teachers observed used $33.7 \%$ of SL and $66.4 \%$ of TL. These percentages are similar in terms of the use of the target language (English), in comparison with the study by Duff \& Polio (1990). The two teachers reported by Duff \& Polio (1990) used the target language in class for $10 \%$ and $68 \%$ of the time. However, there were differences found between the three teachers observed in this study in the amount of SL and TL spoken by each teacher. The three teachers showed a great deal of variation between their use of SL and TL. The following table 3 shows the difference of teacher talk among the three teachers observed and their respective classes.

Tabel 3. The percentage of SL and TL spoken among the three teachers and their respective class

\begin{tabular}{|l|l|l|}
\hline Participants & \multicolumn{2}{|l|}{$\begin{array}{l}\text { English (TL) Percentage } \\
(\%)\end{array}$} \\
\hline & Teacher & Students \\
\hline Teacher A & $71.1 \%$ & $28.9 \%$ \\
\hline Teacher B & $86 \%$ & $14 \%$ \\
\hline Teacher C & $73 \%$ & $27 \%$ \\
\hline
\end{tabular}

Table 3 reveals that Teacher A and Teacher C elicited more students' output in TL ( $28.9 \%$ and $27 \%$, respectively); on the other hand Teacher B used more TL than Teacher A and Teacher C, but she elicited the least students's TL output. In this sense, the comparison of the three teachers in their used of SL + TL, SL and TL is needed. The following table shows the language used by the three teachers.

Tabel 4. The percentage of SL+TL, SL and TL spoken among the three teachers.

\begin{tabular}{|l|l|l|l|}
\hline \multirow{2}{*}{ Participants } & \multicolumn{2}{|l|}{$\begin{array}{l}\text { Percentage } \\
(\%)\end{array}$} & \multicolumn{2}{|l|}{} \\
\cline { 2 - 4 } & SL + TL & TL \\
\hline Teacher A & $12.7 \%$ & $17.3 \%$ & $3.11 \%$ \\
\hline Teacher B & $42.3 \%$ & $58.3 \%$ & $8.9 \%$ \\
\hline Teacher C & $45 \%$ & $24 \%$ & $88 \%$ \\
\hline
\end{tabular}

Table 4 reveals that among the three teachers, Teacher A spoke the least (SL+TL, 12.7\%). Referring to table 3 above, it is clear that Teacher A elicited the most students' TL output (28.9\%). This results indicated that much TL output spoken by the students is associated with much TL spoken by the teacher and small amount of SL spoken by the teacher in the classroom. It is interesting to note in table 4 that Teacher B and Teacher C used even more target language than Teacher A, however they elicited less students' TL output than Teacher A. Interpreting these results only might misslead the research conclusion. Therefore, it is important to know what really happened in each teacher's participant class. For this purpose, Conversation Analysis was used to further analyse the recordings of the classroom interaction between each teacher and her respective class. The section that follows presents teacher language used and its impact on the students' language output. 


\section{Teachers' language input and students' language output.}

In terms of student-teacher interaction, Teacher A avoided to give long and tedious word explanation. She preferred to use other teaching aids such as visual aids in explaining., e.g picture (extract 1) rather than long explanation. In addition, she also provided the students with translation on the whiteboard as part of the input. She believed that if she gave various types of input, it will gave the students time to save the explanation into their long term memory. Munoz (2008) discusses that in addition to the amount of exposure to the target language as an input, it is also necessary to consider the type of input available for the learner. Thus, it is important to identify types of input as well as the quantity of the input. Moreover, when teaching and explaining a new word, Teacher A avoided to give long and tedious word explanation in Bahasa Indonesia (SL). She said that SL could be used to provide a quick translation of an English word which might take time for her to explain. She gave explain the lesson most of the time in English (TL). Accordingly, she provided the students with much exposure to the target language. According to Dekeyeser (2000) and Munoz (2008), younger leaners' memory approach to learning requires a great amount of input, which means that much exposure to the target language is important.

Following is an extract of Teacher's A classroom discourse.

Extract 1. Teacher's A extract of classroom discourse

\begin{tabular}{|l|l|}
\hline SPEAKER & UTTERANCE (S) \\
\hline T & What about this? ((the teacher points to the picture of the Governor in her hand)) \\
\hline S & Governor \\
\hline T & Governor, ((the teacher repeats the students utterance)), this? ((point to the picture of the mayor in her hand)) \\
\hline T & Can you tell again? ((the teacher shows the picture of the governor and the mayor to the students)) \\
\hline SS & Yes, yes \\
\hline S & Governor \\
\hline S & Mayor \\
\hline T & Do you know what picture is this? ((the teacher shows the picture of a king, queen, emperor )) \\
\hline
\end{tabular}

On the other hand, Teacher B and Teacher $C$ gave a long explanation in words (see extract 3 and extract 2, respectively). The difference among these two teachers is Teacher $\mathrm{B}$ gave the explanation in the target language, while it is obvious in extract 2 that Teacher C preferred to use Bahasa Indonesia (SL). Teacher C used SL to explain the lesson to avoid misunderstanding. This finding is in contrast to Ellis (2005: 10) who emphasizes that "everything the teacher does or says in the L2 classroom provides an opportunity for learning the new language, and use of L1 deprives students from valuable opportunities to use, communicate, and process L2". The use of SL might facilitate the learner' understanding, but it hindered their progrees in productive competence (Khanal 2004) especially in the context of EFL learning where the apportunities to listen and to use the TL is limited (Musumeci 1996).

Extract 2. Teacher's C extract of classroom discourse

\begin{tabular}{|c|c|}
\hline SPEAKER & UTTERANCE (S) \\
\hline $\mathrm{T}$ & $\begin{array}{lc}\text { Kemaren } & \text { skillnya berbicara menggunakan "who" } \\
\text { [Yesterday] } & \text { [speaking] [using] }\end{array}$ \\
\hline $\mathrm{S}$ & "Who" \\
\hline $\mathrm{T}$ & $\begin{array}{l}\text { Ya, "who" sekarang kita berbicara tentang skill menulis, jadi nanti } \\
\text { [Yes] [now] [we] [talk] [about] [writing], [so] [later] } \\
\text { disamping anak mam bisa mengungkapkannya dalam berbicara, } \\
\text { [beside] [child] [able] [say] [it] [in] [speaking] } \\
\text { anak mam juga bisa menggunakannya dalam menulis. } \\
\text { [Child] [also] [able] [to use] [it] [in] [writing] } \\
\text { ((the teacher writes "asking and giving information" on the whiteboard)) } \\
\text { ok, jadi kita semua sudah belajar, "asking and giving information } \\
\text { [so] [we] [all] [already] [learned] } \\
\text { by.." }\end{array}$ \\
\hline
\end{tabular}




\begin{tabular}{|c|c|}
\hline & $\begin{array}{l}\text { menggunakan, apa nak? by using apa kita gunakan kemaren? } \\
\text { [to use] [what] [child] [what] [we] [use] [yesterday?] } \\
\text { menggunakan apa anak anak? } \\
\text { [to use] [what] [kids?] } \\
\text { ((the teacher writes "asking and giving information" on the whiteboard)) }\end{array}$ \\
\hline $\mathrm{S}$ & where, when, who, what, \\
\hline $\mathrm{T}$ & $\begin{array}{l}\text { where, when, who, what,((the teacher repeats the student while writing on the board)) ya, } \\
\text { sekarang kita liat lagi kalau what kita } \\
\quad \text { [yes], [now] [we] [see] [again] [if] } \quad \text { [we] } \\
\text { gunakan untuk apa? } \\
\text { [use] [for] [what?] }\end{array}$ \\
\hline $\mathrm{S}$ & $\begin{array}{l}\text { What, apa } \\
\text { [what] }\end{array}$ \\
\hline $\mathrm{T}$ & 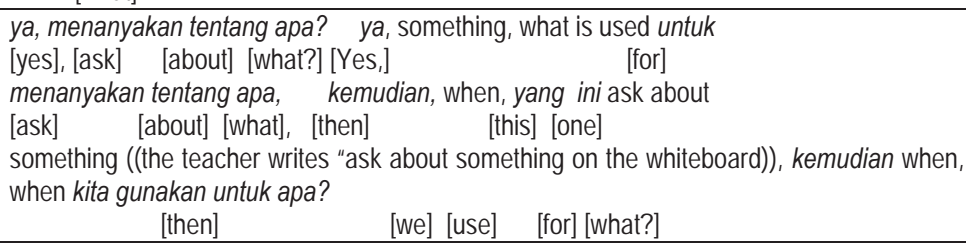 \\
\hline
\end{tabular}

In extract 3, it is clear that teacher B used much English in her teaching, however, her target language used was considered poor, for example in her utterances in extract 3, "And first, actually, home, they are different, do you know what is different? do you know different meaning?". It was not really clear what did Teacher B mean by the word "different", because within the next turn, she also used the word "different" in her utterance but for different puopose.

\section{Extract 3. Teacher's B extract of classroom discourse}

\begin{tabular}{|c|c|}
\hline Speaker & Utterance (s) \\
\hline$T$ & $\begin{array}{l}\text { And first, actually, home, they are different, } \\
\text { do you know what is different? do you know different meaning? }\end{array}$ \\
\hline$S$ & $\begin{array}{l}\text { Perbedaan } \\
\text { Difference }\end{array}$ \\
\hline $\mathrm{T}$ & $\begin{array}{l}\text { Ya, good, perbedaan } \\
\text { [Yes] [difference] } \\
\text { what is the different about has got and has? ok, look at this, I have got or l've got the flu, means the piggy } \\
\text { has the flu, this one is the picture, ok, can you see? } \\
\text { ((the teacher shows the picture of a pig)) }\end{array}$ \\
\hline $\mathrm{S}$ & Yes \\
\hline$T$ & What is that? \\
\hline $\mathrm{S}$ & Pig, pig, pig \\
\hline$T$ & $\begin{array}{l}\text { Pig, ok, good, I have got or l've got the flu, means the piggy has a flu, ok, next, ok, you can see here the } \\
\text { meaning is the fear, } \\
\text { I have the flu means the piggy have the flu, can you see the different? }\end{array}$ \\
\hline $\mathrm{S}$ & Yes \\
\hline$T$ & $\begin{array}{l}\text { But the meaning is still the same,ok? next, today you can see in your books too, we will discuss about kinds } \\
\text { of illness by using have got or has got, number one, cough, what is cough? yes? }\end{array}$ \\
\hline$S$ & $\begin{array}{l}\text { Demam? } \\
\text { [cold] }\end{array}$ \\
\hline
\end{tabular}

It is obvious that Teacher's A students produced more TL as a language output than Teacher's B and Teacher's C students. The interpretation given to these results was that the amount of exposure to the target language may have strong impact on the students' language output. These findings are similar to the findings of Carrol (1975), Meng \& Wang (2011). The teacher's use of the target language in the context of EFL classroom can help leaners obtain effective input 
and output through communication. Overall, the teachers in this study used of Bahasa Indonesia (SL) was more than they expected to use. They used $33.7 \%$ of Bahasa Indonesia where as according to Atkinson (1987), Calman \& Daniel (1998) and Turnbull (2001), the productive use of L1/SL is $5 \%$.

\section{Conclusion and suggestion}

In conclusion, it has become clear that the use of Conversation Analysis in looking at the teacher and the students language use in the EFL classroom is appropriate as it can picture what really happened in the classroom. Teachers in this study used more English in class than their students did. Furthermore, it can be also concluded that the highest amount of Teacher's A target language use influenced her students' target language output. The current study also reveals that the participating teachers also used Bahasa Indonesia (SL) in their teaching, but vary in amount. Based on thses resuls it is suggested that teachers need to be aware of the language they use in the classroom discourse. Teachers are called to consider not only the maximum and optimal use of TL but also in terms of the quality of its use.

Notes for transcription:

Italic = Bahasa Indonesia (SL)

$(())=$ Context

[ ] = Translation from SL to TL

\section{References}

Anton, M., \& DiCamilla, F. (1998). Socio-cognitive functions of L1 collaborative interaction in the L2 classroom. Canadian Modern Language Review, 54, 314-342.

Atkinson, D. (1987). The mother tongue in the classroom: A neglected resource. English Language Teaching Journal, 41, 241-247.

Brook, F. B., \& Donato, R. (1994). Vygotskyan approaches to understanding foreign language learner discourse during communicative tasks. Hispania, 77, 262-274.

Carrol, J.B. (1975). The teaching of French as a second language in eight countries. New York: John Wiley

Chambers, G. (1992). Teaching in the target language. Language Learning Journal, 6, 6-7.

Clifton, J. (2006). Facilitator talk. Vol. 60. Oxford: Oxford University Press, (p. 142).

Cook, V. (2001). Using the first language in the classroom. Canadian Modern Language Review, 57, 402-423.

Cullen, R. (1998). Teacher talk and classroom context. ELT Journal, 52, 179-187.

Cummins, J. (2007). Rethinking monolingual instructional strategies in multilingual classrooms. Canadian Journal of Applied Linguistics, $10,221-240$

Dailey-O'Cain, J. and Liebscher, G. (2009) 'Teacher and learner first language use in foreign language classroom interaction: Functions and applications', in Turnbull, M. and Dailey-O'Cain, J. (Eds), First language use in second and foreign language learning. Clevedon,: Multilingual Matters, pp. 131-186.

Depdikbud RI (Department of Education and Culture Republic of Indonesia). (1993). The Decree of the Minister of Education and Culture No. 060/U/1993.

Depdiknas RI (Departement of Education Republic of Indonesia). (2006). KurikulumTingkat Satuan Pendidikan Bahasa Inggris untuk SD/MI (KTSP) (School Based English Curriculum for Elementary School). Jakarta: Departemen Pendidikan

Nasional.

Dekeyeser, R. (200). The robustness of critical period effects in second language acquisition. Studies in Second Language Acquisition, 22, 499-533.

Diknas (Department of Education, Province). (2010). Laporan Workshop Peningkatan Pembelajaran Bahasa Inggris, Kerjasama Diknas dan Australia. Unpublished report of workshop on improving English teaching, Diknas and Australia. Padang: DiknasPendidikan.

Duff, P.A., \& Polio, C.G. (1990). How much foreign language is there in the foreign classroom? The Modern Language Journal, 74, 154166.

Ellis, R. (1994). The study of second language acquisition. Oxford: Oxford University Press.

Gaies, S.J. (1977). The nature of linguistic input in formal second language learning: Linguistic and communicative strategies in teachers' classroom language. In H. D. Brown, C. A. Yorio, \& R. H. Crymes (Eds.), On TESOL '77. Washington, DC: TESOL.

Gaies, S. J. (1983). Learner feedback: An exploratory study of its role in the second language classroom. In H. W. Seliger \& M. H. Long (Eds.), Classroom oriented research in second language acquisition (pp. 190-213). Cambridge, MA: Newbury House.

Johnson, K.E. (1995). Understanding communication in second language classrooms.Cambridge: Cambridge University Press.

Khanal, K. (2000). A study on the use of Nepali language in English classroom. An Unpublished M.Ed. Thesis. Kathmandu: Tribuvan University

Krashen, S. (1982). Principles and practice in second language acquisition. New York: Pergamon Press 
Krashen, S. (1985). The input hypothesis: Issues and implications. New York: Longman.

Lei, X. (2009). Communicative teacher talk in the English classroom. English Language Teaching, 2, 75-79.

Long, M. H. (1983). Native speaker/non-native speaker conversation and the negotiation of comprehensible input. Applied Linguistics, 4 , 126-141

Long, M. H. (1996). The role of the linguistic environment in second language acquisition.In W. C. Ritchie \& T. K. Bhatia (Eds.), Handbook of Second Language Acquisition (Vol. 2) (pp. 413-468). New York: Academic Press.

Littlewood, W.,\& Yu, B. (2011). First language and target language in the foreign language classroom. Language Teaching, 44, 64-77.

Meng, X., \& Wang, X. (2011). Action study of teacher's language on EFL classroominteraction. Theory and Practice in Language Studies, 1, 98-104.

Macaro, E. (2001). Analysing students teachers' code switching in foreign language classrooms: Theories an decision making. Modern Language Journal, 85, 531-548.

Morata, M., \& Coule, Y. (2012). Teaching English through Spanish: A secondary school EFL teachers' language choices in the foreign language classroom. Porta Linguarium, 17, 133-152.

Munoz, C. (2008). Symmetries and asymmetries of age effects in naturalistic and instructed L2 Learning. Applied Linguistics, 18, 1-19.

Musumeci, D. (1996). Teacher-learner negotiation in content-based instruction: Communication at cross-purposes? Applied Linguistics, 17, 286-325.

Nation, P. (1997). L1 and L2 use in the classroom: A systematic approach. TESL Reporter, 30(2), 19-27.

Neil, P. S. (1997). Language teaching methodology: A textbook for teachers. Englewood Cliffs: Prentice Hall.

Nunan, D. (1991). Language teaching methodology. Hertfordshire: Prentice Hall International.

Nunan, D. (1992). Research methods in language learning. Cambridge: Cambridge University Press.

Nunan, D. (1999). Second language teaching and learning. Heinle \& Heinle.

Paul, D. (2003). Teaching English in Children in Asia. Asia: Longman.

Polio, C., \& Duff, P. (1994). Teacher's language use in university foreign language classroom: A qualitative analysis of English and target language alternation. Modern Language Journal, 78, 313-326.

Raschka, C. Sercombe, P. \& Chi-Ling, H. (2009). Conflicts and tensions in codeswitching in a Taiwanese EFL classroom. International Journal of Bilingual Education and Bilingualism, 12(2), 157-171.

Rolin-lanziti, J., \& Brownlie, S. (2002). Teacher use of learners' native language in the foreign language classroom. The Canadian Modern Language Review, 58, 402-426.

Singleton, D., \& Ryans, L. (2004). Language acquisition: The age factor (2nd Ed.) Clevedon: Multilingual Matters.

Storch, N., \& Wigglesworth, G. (2003). Is there a role for the use of the L1 in a L2 setting? TESOL Quarterly, 37, 760-770.

Swain, M. (1985). Communicative competence: Some roles of comprehensible input and comprehensible output in its development. In S. M. Gass, \& C. G. Madden (Eds.), Input in second language acquisition (pp. 235-256). Rowley, Mass.: Newbury House Publishers.

Swain, M. (1995). Three functions of output in second language learning. In G. Cook \& B. Seidlhofer (Eds.), Principles and practice in applied linguistics: Studies in honor of H.G. Widdowson (pp. 125-144). Oxford: Oxford University Press.

Turnbull, M., \& Arnett, K. (2002). Teacher's uses of the target language and first languages in second and foreign language classrooms. Annual Review of Applied Linguistics, 22, 204-218.

Wesche, M. \& Ready, D. (1985). Foreigner talk in the university classroom. In S. M. Gass, \& C. G. Madden (Eds.), Input in second language acquisition (pp. 89-114). Rowley, Mass.: Newbury House Publishers.

Wong, R. M. H. (2011). Developing teacher awareness of language use and language knowledge in English classroom: Four longitudinal cases. Electronic Journal of Foreign Language Teaching, 8, 19-38.

van Lier, L. (2001). Constraints and resources in classroom talk: Issue of equality and symmetry. In Candlin and Mercer (pp. 90-107).

Zacharias, N.T. (2011). An English teacher struggle to establish voice in the periphery.k@ta, 13(1),64-77 


\title{
Transmitting Local Cultural Knowledge through English as Foreign Language (EFL) Learning as a Means of Fostering "Unity in Diversity"
}

\author{
Yeny Prastiwi \\ Deakin University \\ Melbourne, Australia
}

Doi:10.5901/ajis.2013.v2n3p507

\begin{abstract}
Lack of appreciation of local culture on the part of the public is a continuing concern for many governments. In the Indonesian context, the national and regional governments have a vision to preserve local cultural knowledge as a means to foster the spirit of Unity in Diversity [Bhinneka Tunggal Ika], Indonesia's national motto. Education has been seen as an appropriate forum for fulfilling this aim, and local culture has been incorporated into various school subjects in the curriculum. It has been the policy of the Ministry of National Education that primary school teachers of English as a foreign language (EFL) be responsible for giving students the ability to use English and also an understanding of local culture. Interpretation of policy varies depending on location, however, and may also depend on the individual characteristics and background of teachers. This paper, which is based on a case study conducted in Solo, Central Java, Indonesia, will discuss the ways in which primary EFL teachers contribute to the maintenance of local cultural knowledge. While it has been suggested that language learning is enhanced by study of the culture associated with it (see, for example, Risager, 2007), this paper will argue that learning English as the target language is not always corresponding with learning the culture of the target language (C2). As seen from the students' mastery of English in two different primary schools in Solo, Central Java, Indonesia is supported by using the language to teach about local culture, such as through traditional folktales translated into English. It concludes that the use of local cultural material in the teaching of English as a foreign language serves a dual purpose: supporting mastery of the target language (L2) while also enabling teachers to fulfill their obligation to teach about local culture (C1). The data here presented were obtained through semi-structured interviews with primary EFL teachers and students at one public school and one private school in Solo, Central Java, Indonesia. Using teachers' lesson plans related to the use of folktales as medium for teaching EFL as well as fostering the spirit of 'unity in diversity' amongst the students was another significant instrument to investigate and to collect data about their teaching practice and pictures were considered the most appropriate ones for obtaining students' response.
\end{abstract}

Key words: local culture knowledge; EFL; Indonesia; primary education

\section{Background}

This paper is part of a larger ongoing research paper that I am conducting at present. This paper would like to argue the premise saying learning EFL always associated with learning the culture of the target language. In some respects, learning English as the target language (L2) in the Indonesian context is not always equivalent with learning the culture of the target language (C2). The Indonesian government through its constitutions recommends that education sector should participate in preserving local culture. For this reason, teachers including EFL teachers should make use of EFL teachinglearning process as one of ways to preserve local cultural knowledge particularly within the young generations.

Because of the importance of English as a world language, the Indonesian government supports English as the main foreign language taught in schools. English has, in fact, been widely taught since Indonesia achieved independence in1945 because it was seen as a 'neutral' language following the end of colonization by the Dutch. At present, English is taught from junior high school to university level. To encourage greater participation in education, the government has supported the teaching of the English language education at the primary level since 1994. English remains optional at the primary level, and local content is mandated as part of EFL study at this level. This aims to produce school graduates who are competent in basic English and who have absorbed local cultural knowledge at the same time. Most primary school EFL teachers in Solo, Indonesia choose to incorporate Indonesian folktales into English language lessons as a means of complying with government regulations. Kirkpatrick (2008), who studied English teaching in Indonesia, noted that Indonesian students tend to communicate in English when discussing local cultural information with foreigners (English speakers). This suggests that an approach that is sensitive to local culture may be beneficial for English language education in Indonesia. 
This approach has been taken by a number of EFL textbook authors for the primary level. These texts often contain local cultural presented in English (Jakarta Post, 2011). Many EFL textbooks for the primary level make use of Indonesian folktales which represent a certain region of the country. Not all primary school EFL teachers in Solo, Indonesia use this kind of textbook however, including the two teachers who took part in this study.

The use of EFL textbooks which incorporate Indonesian folktales in translation seems to accommodate the government's aim to produce school graduates who are able to use basic English and who have local cultural knowledge. This idea has been established through various policy documents. The Constitution of the National Education System 2003 Article 1, paragraph 2 defines national education as follows, "National education is an education system based on Pancasila (the national foundation of the Indonesian state) and the 1945 Indonesian Constitution and has roots in religious values and national culture and is sensitive to global change." This constitution also states that national cultural values are expressed in ideology, concepts, social systems, constitutions, and attitudes which represent the character of Indonesia as a nation. Hence, Indonesian folktales may be a possible agent to develop national cultural values that most primary school EFL teachers are willing to use as teaching material. The aim of developing basic competence in English at primary school level has been addressed by placing study of the language under 'local content' as expressed in Decree of the Minister of Education number 60/U/1993. This means that English is an optional subject for primary students. In practice, most primary schools in Indonesia choose English as part of the local content component of their curriculum. The government, through its National Standard Institution of Education, sets guidelines for the standard of competence for primary school graduates. These guidelines are based on standards the four language skills of speaking, writing, reading and listening. While primary school EFL teachers have a strong motivation to teach EFL, they also experience a number of barriers.

The idea that language learning can support mastery of local cultural knowledge may result from anxiety about possible loss of local cultural knowledge among younger Indonesians. Policy makers have tried to address this situation by requiring the study of local culture as a counter to the influences of globalization associated with the English language in Indonesia. Additionally, it may be that the numerous local languages and cultures of Indonesia can be united through the development of certain items of folklore with their inherent values that will be known by young people across the nation. This is seen as supporting the philosophy of 'unity in diversity' through EFL by using Indonesian folktales in translation. Hence, the EFL primary schoolteachers in implementing the government vision related to fostering the spirit 'unity in diversity' amongst the students and its effect on the students basic EFL competence is worth to question and to investigate. The finding of this research paper may come up with the suggestion that learning L2 can a means of learning the $\mathrm{C} 1$. It may oppose the premise saying learning a target language is always associated with its cultural background.

\section{Aim of study}

The aim of this study was to investigate the development of students' EFL skills through the use of Indonesian folktales in translation. Specifically, it was intended to describe and analyze the ways in which local cultural knowledge and English language ability developed in primary school students in Solo, Indonesia.

\section{Research Problem}

This present study involves the investigation of the government regulations and the reality of EFL teaching practice. The central government may have a vision such as preserving local cultural knowledge within Indonesian youths, but teachers may face difficulties in its implementation. In its regulation, English has not been set as an obligatory school subject for the students, yet another constitution recommended having school graduates who have sufficient basic English competence with its good local cultural knowledge as a means of maintaining the spirit of 'unity in diversity' within the youths.

\section{Research question}

1. How the primary EFL schoolteachers in Solo Indonesia implement the government policy for participating in fostering the spirit of 'unity in diversity' using Indonesian folktales in translation in their teaching practice?

2.

3. How the students perceive their EFL learning as means of acquiring local cultural knowledge to foster their spirit of 'unity in diversity'? 


\section{Language and culture teaching-learning process}

Kramsch (1995) noted that "language continues to be taught as a fixed system of formal structures and universal speech functions, a neutral conduit for the transmission of cultural knowledge. Culture is incorporated only to the extent that it reinforces and enriches. Not that it puts in the question, traditional boundaries of self and other." Where culture exists in every language, here she seems to emphasize that language can be a means of transferring cultural knowledge. Yet, the Indonesian context where English is a foreign language, learning and obtaining English language competence seems much enhanced using familiar cultural artifact such as Indonesian folktales in translation which is used as English language teaching-learning materials. It has been suggested that interculturalism is a more achievable goal than biculturalism in L2 study (Byram, 1998). This suggests that English language learners, particularly where English is a foreign language, are generally expected to learn and accept C2 as knowledge instead of accepting and internalizing C2 as norms and values relevant to their daily life.

Language and local culture preservation have often been of political interest in Indonesia. The decision to make English the first foreign language in Indonesia (Lauder, 2008) and the obligation for all academics and teachers to participate in preserving local culture embodied in its constitution and policy documents as described above. Indonesian observers have tended to view traditional literature, such as folktales, as vehicles for the development of a national character based on traditional values. Citraningtyas (2012) suggested that local content, particularly in the form of folktales such as Malin Kundang, might support the formation of national identity and develop students' national culture knowledge. Since this approach has been widely accepted in Indonesia, it is important to understand its impacts and effectiveness in achieving the goals of national education.

\section{Language, culture and identity}

Teaching language involves the teaching of culture as well. A number of authors have suggested that language and culture are inseparable (see, for example, Byram, 1998; Risager, 2005). Risager (2005), however, believes that L2 can be used to teach the culture of the learners. As Kramsch (1997) said that culture exists wherever the language is being learnt. Functioning EFL as the context for local cultural knowledge acquisition makes the students experience a negotiation between their own culture and the cultural knowledge of the target language. Being introduced to the target culture (C2) through teaching materials and class activities essentially helps the students to recognize their own identity that identity formation happened. This phenomenon fulfills the notion of sociological subject in the umbrella of identity concept as defined by Hall, Held, Hubert and Thompson (http://www9.georgetown.edu/faculty/irvinem/theory/Hall-IdentityModernity-1.pdf) and Hall (1996). In response to the growing society, Hall et al also said that one as a sociological subject should realize or aware of his/her being individual is formed in relation to "significant others" which give meaning to his/her existence within the society. In line with this idea, Woodward (1997) affirms that identity of oneself is not a 'unitary entity.' There is a process of 'dialogic circuit' connects one with others; one will be able to identify him/her identity by making relationship with other people. Values, meaning, and symbol as three aspects of culture of the upbringing effect the formation of one's identity (Hall, 1996). In this research, the process of learning local culture through EFL in class has made the students to interact, negotiate and define their own identity. Learning the target language has made the students are not only acquiring sufficient EFL basic skills but also using it to express their own local cultural knowledge as well as to receive information about a foreign culture.

On the other hand, many EFL textbooks lack explicit cultural content ( Sharif and Mohammadi, 2013). In Indonesia specifically, Hermawan and Noerkhasanah (2012) analyzes a number of primary school textbooks which they found to contain very limited local cultural information, despite having been written for use in the Indonesian context, and a considerable amount of implied assumptions about English language users. For this reason, the two EFL teachers - in this present research - look for external references such as Indonesian folktales in translation as an effort provide localculture-sensitive teaching materials. It is at the aim at fulfilling the Indonesian government vision to enrich the students with local cultural knowledge and to enhance the students' ability of socializing with the surroundings. Fortunately, it brings duel benefits for the students: enhancing the students' local cultural knowledge and facilitating as well developing the students' basic EFL competence. It seems that teaching-learning process using Indonesian folktales in translation is seen as social practice. The Indonesian government seems inviting the teachers to see literacy is no longer an autonomous skill but as social practice that is located in a larger institutional context: schools, home, community and possibly larger society (Norton, 2010). Ability of socializing with the surroundings needs students' ability to negotiate within him/her, with the culture of their upbringing, and the culture they are being exposed. Yet, Garuda Pancasila where 
the national motto 'unity in diversity' is inscribed lead the introduction to a cultural artifact such as Indonesian folktales may lead the students to recognize its national cultural identity. They may expect that they students may finally have a strong spirit 'unity in diversity' throughout their being as Indonesians.

Though national identity is not a visible concrete that it is addressed as imagined community (Anderson, 1991; Hall, 1996; Norton \& Kanno, 2003), national cultural identity is a significant element to the existence of a nation. It is apparently the reason of EFL primary school teachers to incorporate Indonesian folktales in translation as their EFL teaching materials to introduce local cultural artifact and to enhance the sense of belonging to local culture. Indonesian folktales as representation of cultural group can be an important part to compose a national culture. Indonesian folktale as a representation of national culture latter constructs national identity, as it is able to connect people from the past, present and future through its texts (though it is initially known as oral literature) and language.

\section{EFL teaching in Solo, Central Java}

The government of Solo, Central Java, has implemented the national requirements for local content teaching by placing three subjects into their local content curriculum. They are Javanese, the local language which is the first language of a significant majority of residents in the region; transitional arts of the region; and English language. Given these three options, most primary schools have chosen English as the local content subject they will teach. However, the requirement that whatever specific subject is taught as part of the local content curriculum must embody the local culture of the region means that EFL teachers have tended to use teaching materials which are culturally appropriate for the context, such as translated Indonesian folktales. The central government does not instruct schools how to teach a particular subject. For this reason, curriculum construction is based on teachers' own interpretation of the rules. In Solo, this has led to the focus on Indonesian folktales in translation as one source of learning material for the study of EFL at primary school level.

\section{Methods}

This case study was conducted in Solo, Central Java Indonesia. It involved two EFL teachers and twelve students from two primary schools, one public and one religious. Semi-structured interviews were conducted with the two teachers who were also required to provide the lesson plans related to their EFL teaching using Indonesian folktales in translation. These lesson plans were also used as the basis for conducting further interviews with the teachers.

The two EFL teachers came from two primary schools with different institutional background. It was expected that these differences in context might impact on the teachers' approach to EFL and their perceptions about the inclusion of local cultural content material in language teaching.

Classes always involve teachers and students in teaching-learning process. Thus, obtaining the students' opinion on the teaching-learning process is the other important step in collecting the data for this qualitative research. The researcher as the interviewer also interviewed the twelve students (six students from each school) to grasp the students' response and opinion on their EFL classes particularly related to the use of Indonesian folktales in translation to learn EFL and its influence to their spirit of "unity in diversity" as part of their cultural identity. Pictures of folktales - Indonesian and western folktales - were considered the appropriate ones to deal with the students who are at the age of 10-12 years old. As Piaget's theory of psychological development - cognitive stages - they are at the age of connecting imagination and reality or thinking abstractly and making judgment of concrete phenomena (http://www2.honolulu.hawaii.edu/facdev Iguidebk/teachtip/piaget.htm). Pictures are expected to stimulate their imagination and to relate it with contexts (content of folktale texts, class activities and society). Pictures of folktales worked well in engaging and attracting the students' attention that they seemed at ease to arrive with their expressions and responses to questions during the interviews.

\section{Teaching EFL through Indonesian Folktales in Translation to foster the spirit of 'unity in diversity'}

Both teachers interviewed as part of this study had difficulty reconciling the available teaching materials with the requirement for local content teaching. Both noted incongruities between the textbooks they were supposed to use and their needs for teaching materials. Textbooks, they explained, were chosen by a group of stakeholders that includes teachers, principals, parents of students, and the school committee. For this reason, they had limited ability to influence the choice of materials and were required to use the texts chosen in this manner. Ms Abia, the teacher at the Islamic private school, commented that she had to adjust in order to accommodate her students' needs, fulfill the local content requirement, and also address contextual issues arising from the institutional background of the school. The fact that it is 
an Islamic school means that the teaching and learning process requires the inclusion of specific values and approaches that fit with the school's orientation.

Nonetheless, both teachers felt that having a textbook as a basis for teaching was valuable and desirable. In their view, a textbook provides an important reference for both teachers and students. Mr Joko, the public school teacher, commented that he feels comfortable relying on a textbook and this makes his preparation easier and more effective. This view is in line with observations in other locations (see, for example, Cunningsworth, 1995; Tok, 2010).

Despite the practicality of textbooks, the two teachers noted weaknesses in their EFL textbooks. Ms Abia noted that the textbook focuses on grammatical use, but this approach is not really appropriate for her primary students. She tends to focus on other teaching methods such as reading as an alternative for students. The ongoing finding of this research, particularly the textual analysis on the EFL textbook supports those teachers' finding that the textbook gives more interest on grammatical concern rather than contextual teaching materials such as Indonesian folktale is not available in the textbook. Therefore, the EFL teachers believe the most effective way to address the shortcoming of the textbooks is through the use of supplementary material taken from other sources.

Ms Abia and Mr Joko look for external references to fulfill their teaching needs. Mr Joko sometimes involves his students in this. He has asked students to look for teaching materials on the internet and then has developed class assignments based on their findings. Ms Abia has more time for her class to engage in learning more activities than the public school provides. In addition to reading and translating texts, she also uses facial expressions and games based on local culture as teaching materials.

The EFL teachers use Indonesian folktales in translation as a medium for teaching EFL. While their main reason for this is the lack of suitable material in the textbook, the two teachers also have additional issues they need to address. Ms Abia, for example, has to consider Islamic values in developing teaching materials. The reading approach that she uses to teach English requires that her students engage in text exploration. Western folktales, such as Cinderella, for example, which is presented in the textbook as a western story for students to study, tend to contain incongruent cultural values. Prince Charming and Cinderella dancing and embracing in public is not acceptable in the Islamic context. Nonetheless, she does explain to her students that such behavior is considered appropriate in an English-speaking setting.

Both teachers are also concerned to promote 'unity in diversity' (Bhinneka Tunggal Ika), as the Indonesian national philosophy. They feel their students are proud to be Indonesian and believe that this aspect of their identity should be fostered through exposure to the diverse culture, values, and characteristics of the nation. Ms Abia, for example, explained that he preferred to teach the story of Bathara Kala which comes from Java or Mr Joko who preferred to teach the story of Malin Kundang which comes from West Sumatera, rather than Cinderella, because the story is Indonesian in origin and because this is a way of contributing to the preservation of local culture.

They are aware of the significance of teaching local cultural knowledge in developing in their students a sense of belonging and an awareness of local cultural heritage. They see this as supporting their students' cultural identity and allowing them to find their place in the increasingly globalized world. Ms Abia notes that students tend to master English more readily and learn it better when they understand the cultural content being presented. They are happy, she says, when they find something they recognize in a text written in English. She places great importance on the teaching of their own culture to students. They need to know about western culture but be awareness and participate in their own.

The two EFL teachers recognize the need for students' understanding of local culture to encompass their own regional culture (in this case Javanese) but also include an understanding of the broader cultural traditions of Indonesia. Mr Joko explains that his goal of introducing Indonesian folktales is to introduce a variety of Indonesian cultures from different part of the country. The diversity of Indonesian culture of culture will become a familiar to the students and they will be moire able to participate in the Indonesian national mainstream.

In this way, the use of a variety of items from different Indonesian cultures may encourage the formation of national identity. The students in Ms Abia and Mr Joko's classes take pride in wearing traditional clothing of their region. Idam, one of the public school students, for example, expresses his identity as an Indonesian by wearing of Javanese clothes. The ability to describe cultural matters in English in a case like this might give the speaker an additional channel through which his personal identity might be expressed.

The internalization of culture through the teaching of Indonesian folktales in EFL can be a means of forming national identity. Most of the students who took part in this study (eight of twelve students) say that they feel more familiar with Indonesian folktales than western ones. The content of the stories, the clothing of the characters which reflect Indonesian customs and cultural values similar to those held by people they know contribute to this. These EFL classes are not the only place where these students can engage in discourse that encourages the internalization of Indonesian 
culture; this takes place in Indonesian classes as well as classes in the local language. Systematic exposure to Indonesian culture creates the possibility of cultural internalization by the students. This internalization involves negotiation within the individuals, negotiation between the culture where they are being raised, and new cultural values they are exposed to. Students are then able to identify themselves as members of a specific cultural and will ideally use their knowledge to support and maintain their own local culture alongside the national culture and the globalized world culture, which is the aim of the national educational process in Indonesia.

\section{Conclusion}

This study shows that the use of Indonesian folktales in translation as material for EFL teaching at primary level in Solo, Indonesia, has benefit for language learning. The teachers involved believe that familiarity with the content of such stories facilitates students' mastery of English and makes them more comfortable using a new language. This outcome is a bonus, as the primary impetus for using such materials was originally to fulfill government requirements that local cultural knowledge be included in local content curriculum of which English is a part of primary school level. Nonetheless, the teachers involved in this study are satisfied that this practice goes beyond simply satisfying that requirement and has real benefit for language learning. These realities show that learning the target language (L2) can be a means of learning C1 (culture of the language learners) instead of associating with and emphasizing on learning C2 (culture of the target language).

Despite this, the teachers note the difficulty of obtaining the required material and have identified various weaknesses in the textbooks they normally use. These books are prescribed by their schools and tend not to contain the required local cultural material. This remains a concern for these teachers, although both feel there is broader value in the approach of using Indonesian folktales in translation in EFL classes and there are concrete benefits for students both in terms of language mastery as well as in terms of personal development of a regional and national identity.

\section{References}

Anderson, B. (2006). Imagined communities. London, United Kingdom: Verso Books.

Kaplan, R. B., \& Baldauf JR, R. B. (2003). Language and language-in-education planning in the Pasific Ba (Vol. 2). Dordrecht, Netherland: Kluwer academic publishers.

Bjork, C. (2004). Decentralization in education, institutional culture and teacher autonomy in Indonesia. International review of education, $50,245-262$.

Byram, M. (1998). Cultural identities in multilingual classrooms. In J. Cenoz \& F. Genesee (Eds.), Beyond bilingualism (pp. 96-116). Clevedon, England: Multilingual Matters.

Crystal, D. (2003). English as a global language (2nd ed.). UK: Cambridge University Press.

Cunningsworth, (1995). Choosing your coursebook. Oxford, England: Heinemann English Language Teaching.

Hall, S. (1997). The work of representation in Representation: cultural representations and signifying practices.(Ed.) Hall. S. 1-74.

Harsono, Y.M. (2006). English language teaching in Indonesia: facts, problems and possible solution. English. edu journal., 5 (2).

Hermawan, B \& Noerkhasanah, L. (2012). Traces of cultures in English textbooks for primary education. Indonesian Journal of Applied Linguistics. VOI 1 (2), 49-61.

Krammsch, C. (1995). The cultural component of language teaching language, culture and curriculum. Language, culture and curriculum. Vol. 8 (2), 83-92.

Kramsch, C. (2012). The cultural component of language teaching. http://zif.spz.tu-darmstadt.de/jg-01-2/beitrag/kramsch2.htm. Retreived: 2nd Oct 2012.

Lauder, A. (2008). The status and function of English in Indonesia: a review of key factors. Makara Social Humaniora. Vol. 12 (1), 9-20.

Mantiri, O. (2006). ELT in Indonesia: what culture should be taught? elt-indonesia.blogspot.com/ 2006/culture-sensitive-approach-inelt.html.

McKay, S.L. (2000). Teaching English as an international anguage:implications for cultural materials in the classroom. TESOL journal, Vol. 9 (4), 7-11.

Nault's (2006). Going global: rethinking culture teaching in ELT contexts. Language, culture and curriculum. Vol. 19 (3), $314-328$.

Risager, K. (2005). Languaculture as a key concept in language and culture teaching in The Consequences of mobility. (Ed.) Preisler, B., Fabricious, A., Haberland, Hartmut., Kjaerbaeck, S. \& Risager, K. Roskilde: Roskilde University, Dept. of language and culture, 185- 196.

Risager. K. (2007). Language and culture pedagogy: from national to a transnational paradigm. UK: Multilingual Matters Ltd.

Saragih, B. BT. (2012). SBY reminds of importance of 'Bhinneka Tunggal Ika'. Jakarta Post. 12 ${ }^{\text {th }}$ August 2012, Thursday. http://www.thejakartapost.com/news/2012/08/02/sby-reminds-importance-bhinneka-tunggal-ika.html

Sharif and Mohammadi. (2013). Cultural, national identity, and globalization between the lines of reading comprehension texts in Iran. Elixir Ling. \& Trans. 56, 13452-1345. 
Smith, J. \& Wiese, P. (2006). Authenticating children's literature: raising cultural awareness with an inquiry-based project in a teacher education course. Teacher quarterly, 69-87.

Sugirin, Sudartini S, Suciati \& Lusi Nurhayati. (2011). A study on cultural intergration in the English textbooks for junior high schools. Litera, Journal of language, literature and applied teaching, Faculty of Language and Arts, State University of Yogyakarta Indonesia. Vol 10 (2), 235-246.

Tok, H. (2010). TEFL textbook evaluation: from teachers' perspectives. Educational Research and Review Vol. 5 (9), $508-517$.

Woodward. K. (1997). Identity and difference. England: Sage Publications Ltd. 
